\title{
Regarding the pain of mothers The First World War, Anna Lenah Elgström, and fiction as media
}

\author{
Sofi Qvarnström
}

\begin{abstract}
To designate a hell is not, of course, to tell us anything about how to extract people from that hell, how to moderate hell's flames. Still, it seems good in itself to acknowledge, to have enlarged, one's sense of how much suffering caused by human wickedness there is in the world we share with others. ${ }^{1}$
\end{abstract}

In her essay Regarding the pain of others (2003), Susan Sontag discusses the meaning of the photographic image in war. Photography cannot prevent war, nor relieve human suffering. But it can bear witness to the war, and thereby teach us something about the world and the human condition. In the passage on suffering it is not obvious that Sontag is talking about the photography, though; it could just as well have been a television programme, a newspaper article, or a piece of fiction writing. What Sontag is describing is a fundamental function of media in wartime.

There are, of course, fundamental differences in the representation of war and suffering that depend on the type of media, since both medium and genre limit what can be represented. We have seen an increased awareness of the importance of the media type in narrative in recent decades, even if these ideas are not new. In the sixties, Marshall McLuhan coined the well-known expression 'the media is the message', but as far back as Aristotle's Poetics we can find a discussion of media (even if he did not use the term medium, which is derived from Latin). Aristotle understood the medium to be an expressive resource, such as colour, shape, rhythm, melody, or language (voice). 
Thereafter he classified different art forms according to the media they use-for example, music (melody and rhythm) and dance (rhythm only). ${ }^{2}$ However, it is only in recent years that the axiom of narratology, as a project that transcends disciplines and media, has been called into question; hence the two volumes edited by Marie-Laure Ryan, Narrative across media (2004) and Storyworlds across media (2014), which raise the question of how the intrinsic properties of a medium shape the form of the narrative, and how narratives mutate and create new meaning as they migrate to another medium.

In terms of theory, this chapter develops ideas from these two works, but also adds a rhetorical perspective on media analysis. I have earlier argued that a rhetorical focus in media analyses brings a methodologically complementary perspective to a discussion of cross-media relations. ${ }^{3}$ At the time, I was concerned with persuasiveness, and the ways in which a message changes when it is formulated in a range of media. Persuasion works differently depending on how its arguments are formulated: verbally, in writing, or figuratively. Where the arguments are made-in newspaper articles, in novels, or in parliament-must also be taken into account. A rhetorical perspective, unlike a narrative approach, emphasizes the fact that content, form, and representation not only create meaning, but do something to us, affecting or changing us in different ways. What I discuss here can be seen as a development of my previous work, but now with a focus not on media transcendences, but on the characteristics of rhetoric in a single medium: fiction books.

My aim with this chapter is to investigate fiction as a medium, and its role in representing war, death, and bodily suffering. More specifically, it concerns depictions of the First World War (1914-1918). What characterizes the fiction about this war, and what are the possibilities and limitations of the medium? This will be discussed using a number of short stories by the Swedish writer, Anna Lenah Elgström (1884-1968).

\section{Fiction as a medium}

The concept of medium has been much discussed and its definitions are numerous. ${ }^{4} \mathrm{~A}$ recurring definition is that a medium is a combination of modality (language, sound, image, moving images, music) and a physical channel (a book, newspaper, painting, or debate, for 
example). Yet a medium also consists of technology (whether speech, writing, print, film, television, or digital technology) and has a cultural dimension-'the public recognition of media as forms of communication and the institutions, behaviours and practices that support them. ${ }^{5}$ Comics, the theatre, and the press are all examples of media types where the cultural dimension is significant-media forms cannot be distinguished between purely on the basis of modality, physical channel, and technology. In what follows, however, the main focus is the modality (language), the physical channel (book), and the technology (writing) of fiction, putting to one side the fact that a book is a printed medium.

In order to talk about what characterizes a certain medium, we have to relate, directly or indirectly, to other media. Wallace Chafe can talk about the slowness of writing because he compares it with speech. Where spoken language is ephemeral, written language is permanent and transportable; where speech is often spontaneous, writing is, for the most part, deliberate and 'worked over.' ${ }^{6}$ If we focus on the physical channel or the materiality of a book, and compare it with a newspaper, we will find a temporal difference similar to the one between spoken and written language: the process from writing to publication takes months, and often years, whereas it takes approximately a day for a newspaper. It is not only the production process that is characterized by slowness, of course, as reading and reception can be much the same. A newspaper might be read in a matter of hours-each article takes only a few minutes-but a book can take several hours, and often days, to finish. Another way to trace media-specific properties is to look at the development of new media. ${ }^{7}$ To take one example, it is only when we start to discuss multimodal texts, which use several means of expression (for example, words and images), that we become aware of the mono-modality of written language (only words). ${ }^{8}$

The following discussion is organized around a number of properties or features, which characterize both the book as a medium and the fiction genre. The question is the extent to which these properties affect the representation and mediation of war, death, and bodily suffering. These features can either be linked to the writing and production process of the book, to its materiality, or to its reception. In this chapter, then, I present the evolution rather than the test of a theory, for instead of beginning with a complete theory (top-down), the five properties I 
discuss here emerged during the empirical work (bottom-up). This resembles the method applied by Ryan in her discussion of what defines a medium. ${ }^{9}$

\section{Elgström, Sweden, and the First World War}

One aim with this chapter, in other words, is to examine how suffering and death was represented and mediated during the First World War. ${ }^{10}$ However, the short stories chosen for my analysis should not be thought especially representative for the time. They are one illustrative example out of many. Anna Lenah Elgström may be forgotten today, but during her lifetime she was a prominent voice in Sweden's public life as a writer, journalist, feminist, pacifist, socialist, and founder of the Swedish section of Save the Children. Her writing was driven in a more overtly political direction by world events in 1914, and in one way or another the war permeated almost everything she wrote thereafter. She was one of the Swedish writers who most vociferously criticized the war at the time. ${ }^{11}$ Sweden was not a combatant and observed events at a distance; however, even though the country had declared itself neutral, there was a clear tendency to take sides, with the conservatives sympathizing with Germany and the liberals and the left with the Entente Cordiale. ${ }^{12}$

Elgström's collection of short stories, Mödrar (1917, 'Mothers'), includes nine short stories exploring the changing meaning of maternity. She depicted motherhood as a life-giving and liberating force, but also as a form of bondage that prevented women from taking part in the world and meeting men on equal terms. This tension was a central conflict in Elgström's feminist pacifism. Another was the opposition between the notion of a tender-hearted, self-sacrificing motherhood and an active, radical, societal motherhood that demanded a degree of selfishness and contrariness. The overall structure of the short stories can also be described as a battle between two conflicting principles: mothers are life incarnate, creating and cherishing life and earth, while war represents the death which will devastate them.

Elgström was strongly influenced by the Swedish social reformer Ellen Key (1849-1926), whose notion of her own coinage, societal motherhood ('samhällsmoderlighet'), was thought crucial to peacemaking. Key's 


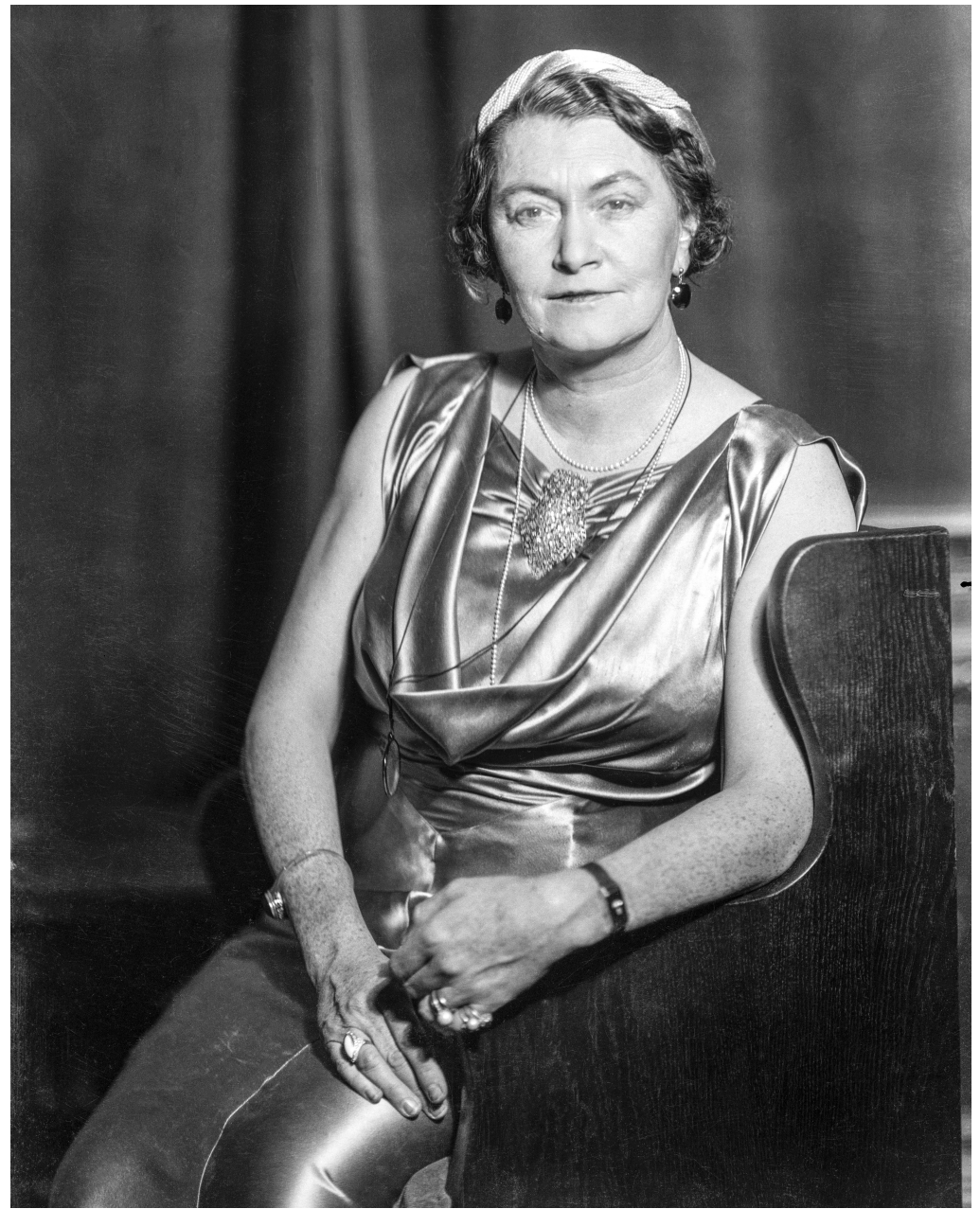

Portrait of Anna Lenah Elgström (1884-1968) by Jan de Meyere, 1925-1941, Stadsmuseet, Stockholm.

societal motherhood should be understood as a moral and political concept-a metaphor for women's participation in society and public life. She wanted to subject one-sided male power to a female corrective. ${ }^{13}$ Women's suffrage was a necessity if women were to be able to participate and influence society in a fresh direction. Consequently, the tasks that women had acquired through motherhood, such as nurturing, protecting, and educating children, would gain in stature 
in the public sphere. In the war years, motherliness and maternal care would be emphasized as invaluable for promoting peace not only in Sweden, but throughout Europe. ${ }^{14}$ The crux of this so-called maternal pacifism was that women, as potential or actual mothers, had developed certain abilities that made them want to save their children from all harm. Since war took the most violent of forms and led to the worst consequences, women were supposed to oppose war.

The two short stories that are my particular focus here, 'Ur kaos' ('Out of chaos') and 'Spökbarnen: En sann historia' ('The ghost children: A true story'), depict physical and material experiences in wartime. ${ }^{15}$ In the first story, the reader meets a woman desperately digging for her child in the ashes of her burnt home. When the child, who has miraculously survived, comes crawling towards the mother, a reunion is impossible: the child does not recognize her, but is frightened by her distorted figure. The mother turns away in pain and lets the child crawl on, 'out of chaos, into life itself, the new, forgetful, forgiving life. ${ }^{16}$ 'The ghost children' describes a mother's anxiety at not being able to feed her children properly in war-torn Berlin. She is haunted by visions of emaciated and deformed children, and she is afraid her youngest son will develop the same deformations. She also dreads her husband's leave from the army, which for her part is always followed by a new pregnancy.

\section{The genre conventions of fiction}

All kinds of communication can be said to be a combination of genre and medium. However, it is not evident that one should distinguish between them, especially considering the many definitions that exist of the two. Ryan offers a useful definition when she argues that the differences concern the character and origin of the restrictions on both genre and medium. The restrictions on genre are conventions-relatively arbitrary rules, of course, but the result of the culture in which they exist. Genre uses those restrictions to channel expectations, optimize expression, and facilitate communication. The restrictions on medium (which could just as well be possibilities) are dictated by its materiality, modality, and technology, which the medium then forces on the user or audience. You choose a medium for its possibilities, while you try 
to work around or compensate for the negative restrictions. ${ }^{17}$ For example, fiction compensates for its lack of images by using metaphor, symbols, and variations in style. In this way, it tries to paint with words and create evidentia. In the following, I want to explore how some of fiction's genre conventions interact with the medium, and how that affects representations of war and bodily suffering.

The most distinctive genre convention of the fiction book is, not surprisingly, its fictionality. A fiction is something made up, something that imitates reality without being reality. ${ }^{18}$ Needless to say, not having to answer to truth claims of various kinds gives an author far greater freedom. In order to answer the question of how this affects the representation of war and suffering, Elgström's short stories will be compared to other non-fiction, such as newspaper articles, pamphlets, and reportage. At first glance, it looks as if Elgström's theme in her short stories is the same as in her prose contributions to public debate. ${ }^{19}$ In her collection of short stories, the reader meets women with unconditional love for their children; women who are willing to sacrifice themselves for their children or for a higher idea; women who protect the weakest in society; women who embody the qualities that will change the world and prevent war. But where the articles and pamphlets mostly contain exhortations, the short stories depict the sequel-the consequences of the mothers' actions. Do they manage to break with the warlike structures and male dominance of their lives and bring about change, or are they themselves broken down? The answers are ambiguous, and it is obvious that the mothers encounter resistance. Here, there are no women who take an active part in politics and public life, but instead women who succumb to the war, but are portrayed as role models since they sacrifice themselves for something bigger and more important.

In other words, Elgström problematizes maternal pacifism in her short stories. Her fiction is far more pessimistic in its view of women's possibilities in wartime. In the two short stories 'Out of chaos' and 'The ghost children', each woman's time is totally taken up with childcare. Making sure the children will survive takes all her time and efforts, to the extent that each succumbs. Such an end testifies to the tyranny of motherhood in a time of war, but what Elgström does by relating this experience in a fictional form is to verbalize the experience, making it visible despite its private character. Ultimately, it is a human conflict 
that she depicts: the difficulty of simultaneously reconciling dependence and independence, altruism and egoism. The fact that she dares to be more pessimistic in her fiction is probably linked to its absence of direct reference to reality. An author does not need to answer for a fiction story in the same way as for a debate article, but can hide behind the veils of fiction.

One genre trait associated with fiction is internal focalization, a narrative technique where the narrator's point of view largely coincides with the protagonist's, enabling descriptions of events from within a character. The narrator sees, thinks, and feels with the character. ${ }^{20}$ Internal focalization is apposite to Elgström's brand of feminism, given that it is a conscious strategy that can give a voice to silent or forgotten women, and to show their thoughts and feelings in their own right. She is inclined to modernism, a style which often focuses on the subjective experience and the inner consciousness, and her narrative technique promotes the emotional and subjective experience, and enables identification between protagonist and reader.

In 'Out of chaos', internal focalization is used to depict how war destroys the mother and the values associated with her. ${ }^{21}$ The mother, who finds the body of her dead husband in the ruins of their home, appears more thing than human, mechanically continuing to dig through the ashes; instead, it is the threatening environment that is given a human form: she senses the darkness standing guard, the silence holding its breath in excitement. ${ }^{22}$ When she sees her own reflection in the window of an abandoned patisserie, she no longer recognizes herself: 'The thing stared at her from there, too-a blank white spot; a meaningless, scary, empty surface-her own face. But she did not understand it, no longer understood the meaning or context of anything, at one with chaos, dissolved in its nothingness. ${ }^{23}$

The first part of the fourteen-page story focuses entirely on the mother's experiences, and begins in medias res to emphasize her chaotic impressions. One-third in, the narrative is suddenly interrupted with the words, 'Then, the miracle happened. ${ }^{24}$ The focalization is now transferred to the lost child, who is crawling among the piles of stones and corpses, searching for her mother. It is in the meeting of mother and child that Elgström's handling of the internal focalization is at its most effective. The point of view is transferred from the child, via the narrator, to the 
mother, when she recognizes her child. The child sees only a terrifying, ghostly phantom, but with the help of the narrator, the reader also sees a woman teetering on the verge of madness, having to muster all her strength to make sense of what she sees. The woman-a stranger, a mad thing-is no longer a mother, but yet she still recognizes her child. When she sees 'clear tears of horror' running down the child's cheek, the woman turns her head away, ready to give her child up and leave it to face a new life on its own. For the woman, it is too late. She falls back into the ashes, 'whose darkness embraced her as if to mercifully conceal her; to forgivingly efface her and everything that was hers. ${ }^{25}$

As a consequence of the dual exposure of the meeting, the same emotional event is related twice from two distinct perspectives. The child's fear of the phantom is in heart-breaking contrast to the mother's joy of recognition, and that joy is forced to give way to fear. Consequently, the narration enables a double identification, both with the child and the mother. As a result, the reader's empathy is strengthened, and the fate of the mother and child remains a brutal testimony of the cruelties of war.

\section{The reception situation}

It is not only the narrative technique that is designed to provoke the reader's empathy, but its reception too. The commonest way to experience fiction is by reading silently to oneself, alone. Unlike television or films, which are often watched together with others, print fiction is almost invariably a private and individual encounter. Thus, the reader's personal interpretation becomes more important in fiction, at least initially. The gaps (Leerstellen) that a text always contains, according to Wolfgang Iser, and which the individual reader must fill in to create meaning, are filled with different content depending on the reader's individual knowledge and previous experience. ${ }^{26}$ Also, since fiction often sets out to be deliberately ambivalent, unlike journalism for example, the fiction book can generate a greater range of interpretations of one and the same story.

We find an example of this in the short story 'The ghost children.'. The story examines the thin line, eroded by the war, between reality and imagination. It begins in a realistic style with a distinct narrative voice, which with carefully evaluative wording locates the story in a 
well-known contemporary place: a tenement house in Berlin in the third year of the war. Women and children live in constant fear while the men are at the front fighting. Their existence is equated with that of the men in the trenches-everyone, regardless of sex, is at war. The narrator's initial function is to strengthen the social critique voiced in the short story.

Then, suddenly, the perspective narrows to the experience of an increasingly desperate mother. The language changes character, taking on an expressive and personal tone. By alternating between internal and external focalizations, Elgström creates uncertainty about what is real. Initially, it seems Mrs Mayer knows that the deformed, ghostly children she sees are visions, but in the next paragraph that is questioned: 'But the worst of all was, that they so often were real. ${ }^{28}$ It remains unclear whether it is the narrator or the mother speaking here. The next time she catches a glimpse of the deformed children, she once again doubts her senses.

This passage is open to a dual reading in which her offspring simultaneously represent the real starving war children and her anxiety for their health. The uncertainty about what she is actually seeing remains when, on the doorstep to her home, she discovers another 'ghost child': 'a small, skeleton-like, half-year-old tot who, at her cry, laboriously lifted his abnormal, dangling head on his narrow stalk of a neck, which at every moment seemed ready to break under its weight, and looked upon her with big, dark, suffering eyes. ${ }^{29}$ It turns out to be Mrs Mayer's own son there on the threshold, a sight that becomes too much for her and she falls to the ground in a faint.

Even in the older children, she sees signs of sickness: 'There the children sat around the dinner table under the hanging lamp, which illuminated their faces with a sharp light, causing their bones to stick out from under their death-pale skin, as if corpses. But these little skulls grimaced from crying, silent and helpless now. ${ }^{30}$ Again, an alternative picture is added to the story, this time by her husband when he looks at the children around the dinner table: 'Everything seemed to him to be in order now-happy, healthy children-albeit skinny and pale-hardened by destitution-Germany's great age strengthened-.' ${ }^{31}$ By weaving the narrator's path in and out of the characters' minds, Elgström destabilizes the boundary between inside and outside, reality 
and imagination, not only for Mrs Mayer, but for the reader too. The initial realism of the text, which after all has the subtitle 'A true story', collapses in on itself, ebbing out as several stories in one. Mrs Mayer gives a voice to all oppressed mothers during the world war. Her truth is not the truth of her husband, and the inner contradictions of the text effectively question whose truth is legitimate during war.

Thus the story is receptive to multiple or parallel readings. This is especially true when it comes to how the reader should interpret its ending. The last few lines show that the husband still has priority in defining reality, because Mrs Mayer's experiences are drowned in the jubilation of victory, and all mothers' losses of their sons are transformed into land conquests. In the narrator's words: 'How it looked under the surface-what a small, grey atom Mrs Mayer felt, when she lay down next to her slumbering husband and sensed the ghost children tip-toeing, crawling up her body, nestling in her arms, whispering: Mother! Mother! - it - well, it does not matter at all, ${ }^{32}$ all while the husband's truth is undermined by the ironic tone. But the question is how to interpret this fruitless end? The overall tenor of the story is very clear throughout-war is a destructive force that hits women and children particularly hard-but what is the role of the idea of societal motherhood? Can women help change the world so that life and love conquer the forces of destruction? One interpretation after reading 'The ghost children' and 'Out of chaos', in which the women die or are silenced, is that their struggle is futile; another, especially if the reader is aware of Elgström's political ideas and journalism, is that the war will force a change in the state of the world.

\section{The modality of the book}

The main modality of the book is language. Unlike, for example, newspapers, movies, television and children's books, literary fiction for adults is not multimodal-it rarely uses multiple modalities at the same time. For someone who hopes to affect readers emotionally and make them take a stand against war, it would be advantageous to use images. Images have a special ability to stir the emotions, because they consist of iconic signs which seem to depict something present, and not, like the symbolic signs of language, to represent something absent. ${ }^{33}$ 
Emotions arise when we think we see something that we recognize from the real world-and it is the same emotions that we would have experienced if we had seen it in reality. This is why pictures are said to develop a series of programmed emotional responses. ${ }^{34}$ For a writer, though, language is the only tool available with which to testify to the immeasurable suffering of war. By using detailed descriptions, writers try to create vividly illustrative images (evidentia). ${ }^{35}$

Symbolism and imagery are important in Elgström's work as she illustrates the everyday life of war using several different literary styles. ${ }^{36} \mathrm{Her}$ short stories are rooted in a realistic tradition, her themes are always contemporary. Her explicit criticism of gender relations develops the problem-oriented prose of the Nordic women writers of the 188os. Like Alfhild Agrell-who in the drama Räddad ('Saved') from 1883 paints a pessimistic picture of women's opportunities to leave home-Elgström depicts women's imprisonment in patriarchal structures. Unlike Henrik Ibsen's Ett dockhem (A doll's house) of 1879, however, their texts express a far greater pessimism in their view of women's chances for liberation. Viola in 'Saved' cannot leave home until after her son's death. In all Elgström's short stories there is a pervading critique of the misogynist social system that women are forced to live in. And war appears as the ultimate consequence of this system.

However, when representing human suffering, the realistic narrative gives way to another form of prose. The mother's anxiety at not being able to protect the life she gave birth to is narrated in expressionist language. In 'Out of chaos' reality is said to be broken, and the world in which the despairing mother moves appears threatening and uncertain:

Mere shadows-shadows of dark shores pounded by thunderous waves, shadows of steep paths winding all the way up to the wild clouds, high shadows of black cliffs around which vultures cried, and the gloomy shade of deep, autumn-red woods, where the falling leaves silently hid bloody corpses with mysterious, mouldering faces-an endless, shadowy jungle of sinister dreams, through which she vainly struggled to reach clarity about what was real, and what not, ridden by demons in a flickering dance, which always ended in the same place. ${ }^{37}$ 
The landscape she evokes is reminiscent of the poem 'Ångest' ('Anguish') from 1916 by the poet Pär Lagerkvist, one of the more prominent early Swedish expressionists. Lagerkvist's poem also has images of forests, cliffs, and clouds piling up, blood, and darkness, albeit highly stylized. It has been characterized as one of the most obvious Swedish examples of the expressionist landscape, where the scenery is 'a projection of the experience', and the bare landscape is said to enhance the fundamental feeling he wants to convey: 'As naked as this reckless

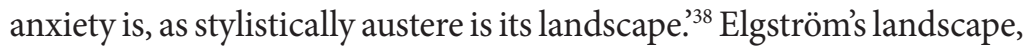
unlike Lagerkvist's, is anchored in the material world and rather is a reflection of the woman's state of mind, yet her reductionism and austerity function in the same way.

Another central expressionist topos found in both short stories-and in Lagerkvist's poem - is the scream. ${ }^{39}$ In the visual arts, it had already been isolated as a theme in 1893 by the Norwegian painter Edward Munch. In 'Out of chaos', silence has 'stiffened to a silent scream of despair,' ${ }^{40}$ and in 'The ghost children', Mrs Mayer chokes back a panicked scream in order not to wake her sleeping husband). ${ }^{41}$ The scream motif is also found in several of the other short stories in the collection. In 'The spirit of gravity', which alludes to Nietzsche's Also sprach Zarathustra (1883-85), Elgström paints a frightening portrait of the burdens and slave-like state of motherhood, in which Mrs Björkman regrets that her male friends fail to see poetry as 'a scream from the heart, the blaze of a life's eternally burning, secret fire' ${ }^{42}$ Elgström much later expressed a similar view of literature, explaining that 'Mothers' was not a book, but 'a cry from a woman who was, without exaggeration, almost scared to death by what she saw. ${ }^{43}$

Piotr Bukowski has discussed Lagerkvist's collection of short stories Järn och människor (Iron and men) from 1915 in terms of German expressionism, arguing that the scream appears mainly in two forms: as the scream with no subject, and as the collective scream. ${ }^{44}$ In the first case, the origin of the scream is unknown, detached from human agency. The collective scream erupts from wounded soldiers, but calls to mind the thunder of artillery on the battlefield. The human scream, the most immediate expression of the individual's inner being in extremis, is turned into something strange and impersonal. For Bukowski, Lagerkvist's use of the scream is an expression of how war alienates 
man from himself, and forcing him into a mechanical ordering. In Elgström's 'Out of chaos', the scream-despite being silent-can be said to serve a similar function. It comes from the woman and becomes one with the chaos that she meets: 'The silence around her had somehow stiffened to a silent scream of horror. Her own mouth was open, but although ready to burst with fear, she was unable to draw her breath, could not understand what she saw. ${ }^{45}$

The expressionist style is used fluently here to create evidentia; however, it is not limited to vivid, emotional waves of expressionism. When the panicking mother runs from her burning house and stumbles across her husband lying on the ground, it is the materialistic and naturalistic descriptions that conjure up the dead man in front of her:

- when in the same minute, in her frenzy, she bumped into an object on the ground, and, tumbling over it, she suddenly looked into her husband's dead face, where not his friendly eyes, not his happy face, but his red meat, his bones, crushed and caked in bloody mud, stared at her-then it was as if the abyss of horror had swallowed her own brain, and spread out into a predominant meaningless emptiness. She looked into the red mask which had been her husband's face, and all that stared back at her was the thing-the unknown, incomprehensible $i{ }^{46}$

A third way of visualizing the boundless suffering of war is symbolism. Elgström's symbolism relates to an imagery of decadence. In 'The ghost children', Mrs Mayer visits one of the families who has made a fortune out of the war by speculating in food. The family has decorated their mansion with war trophies and art treasures, and Mrs Mayer walks through the halls and salons looking for the family's son, who has hidden himself somewhere. In a room reminiscent of a crypt, the tables groan under the weight of busts and animal sculptures, all with stiff, obscene grins. She feels ill at ease, and understands that it is because they remind her of the deformed children's excessive heads that she sees on the streets of Berlin and in her mind's eye. Suddenly she catches a glimpse of a life-size ivory image of a deformed child who looks like it was alive: 
Through the sedan chair's greenish glass its appearance was disgustingly similar to a foetus in a glass jar, almost seeming to vibrate with an awkward, somehow galvanized life.

She stepped backwards, staring at it in fascination-God in heaven, she was persecuted! Could she never escape reminders! It looked at her as if it were alive-sadly and reproachfully, enigmatically accusatory, like the others, the living children - with a firm, blind gaze that made her sick with horror, from its big, black stone eyes in the little pale, bloodless bone face over which the rest of its head hung, like an obnoxious outgrowth, a giant, white sponge-

... Yes, it moved-the stone eyes closed half-way in the ancient little face, the nose-like, animal opening of the mouth slowly unclosed with a feature of inhuman, sad wisdom — the monster emerged $-{ }^{47}$

Of course, it is the family's son whom Mrs Mayer encountered, he too one of the emaciated and sick children of war. Mrs Mayer, 'half-unconscious from horror', rushes away from the child, out of the house. Afterwards, arriving home, she sees the ghost child in her own son on the stairs. Fainting, she miscarries.

The symbolism of decadence is there in the feeling of disgust that permeates the description of the character and in the accompanying metaphors of plants and degeneration. The loathing that Mrs Mayer initially experiences when she looks at the figure she thinks looks like a preserved foetus, remains when she realizes that the child is real. Her open disgust at the child is in sharp contrast to the other child portraits in Elgström's collection, which depict the symbiosis between mother and child and the mother's all-encompassing love. Instead of representing the usual hope for the future, the children in 'The ghost children' are emblematic of a degenerate world and an equally degenerate bourgeoisie that the world war has generated-or perhaps it is they who have generated the world war. She even contemplates taking her youngest son's life to save him future suffering. Such a radical questioning of maternity and childbirth is unusual in Swedish war literature. ${ }^{48}$

Like many contemporary writers, Elgström links the world war with degeneration and decay. Decadent literature is often described as literature that thematizes the feeling of dissolution of the world and its values, and the decay of culture and the subject, and as such 
it is a literature that emphasizes surface and artificiality. ${ }^{49}$ But unlike the decadent writers, who most often traced degenerate tendencies within the individual, Elgström located the degeneration to a particular perception of society, embodied by the war. The phenomena could be called an externalization of decadence. ${ }^{50}$ Elgström's socialist social criticism is reserved for a patriarchal, nationalist ideal and the greed and expansionist plans of those in power.

\section{The permanence of the book}

We have seen Elgström employ a variety of styles in her portrayal of the suffering of women and children in wartime. We can view these short stories as samplers, bringing together a range of literary motifs and styles-romance, realism, naturalism, decadence, and expressionism -in prose that both looks backwards and, given that we are reading it today, a century later, forwards too. A book, unlike a newspaper or the radio, is a permanent and transportable medium, often consumed long after it was printed. ${ }^{51}$ That means that today it is possible to see the links to modernism, which, when the book was written, was in its infancy. Today, the distance in time is sufficient to reveal to us the similarities and differences between Elgström and the decadent writers. Reading changes according to time and context, and the interpretations only multiply.

Even in Elgström's time, though, reviewers were alert to the boundary-crossing features in terms of language and style. When characterizing her short stories, they used the most varied epithets and descriptions, some emphasizing the realism and the links to the realist tradition of the 188 os, others highlighting the visionary, metaphysical element. ${ }^{52}$ But instead of concentrating on variations in style, the reviewers homed in on one feature at a time in their reviews. The one thing they could all agree on was Elgström's sentimentality. All the reviews mention something of Elgström's fervent pathos, her passionate voice, and her fierce indignation. However, her sentimentality was not linked to a modernist aesthetic until much later-in fact, only in the late twentieth century, by Catrine Brödje. ${ }^{53}$ The fact that Brödje saw Elgström as belonging in the feminist, modernist tradition can also be regarded as a consequence of the time Brödje lives and works in. Since 
the 1970s, feminist literary research has expanded exponentially, one of its significant achievements having been the revaluation of women writers. In other words, Elgström's becoming a modernist pioneer at Brödje's hands is very much in line with this tradition.

When the reviewers remarked on her decadent themes, they did so primarily in direct or indirect comparisons with the decadent poets. ${ }^{54}$ Elgström alluded to the symbolism of plants which the decadent poets cherished - the evil flowers of Charles Baudelaire and the Sensitiva Amorosa of the Swedish writer Ola Hansson, among many others-by repetitively comparing the children to sick flowers: 'Around her, they lifted their large, pale skulls from the darkness, like strange, sick flowers - the fading shoots of something, which was withering away- ${ }^{55}$ This, of course, makes it possible to establish what distinguishes Elgström from the decadent writers. Instead of the decadents' nexus of women, flowers, and sexually transmitted disease, Elgström's children carry another kind of metaphoric disease- the contagion of war, which spreads poverty and decay. Elgström rephrases the decadent theme so that it is war, not emancipation or sexuality, which perverts men and makes them sick. The layers of interpretation of the decadent theme created over time lend greater complexity to the narrative.

What then has the permanence of this particular book meant for the depiction of war, suffering, and death? Fiction is universal in a way that many other media are not. Elgström's short stories depict mothers' suffering in the First World War and the situation of all mothers during war. The world today has since experienced yet another world war, and a series of minor and major conflicts, some of them still ongoing. Links are created between the world then in 1917 and the world now, the stories bearing witness to what has changed and what has remained the same. Even though the collection's interest does not lie in its topicality-which explains the permanence of the book-it is sufficiently embedded in the First World War era to give the reader a sense of the causes and consequences of precisely this war: 'Soldiers! New soldiers! the cry sounded all over Germany. In newspapers, at meetings, everywhere women were called on-Do your duty! Give birth, so that Germany may remain strong! ${ }^{56}$ Elgström depicts a society in which the individual only exists to serve the state and increase its power; a society where the rich only pursue greater wealth, at the expense of the poor. The war, 
matched with the state's determination to expand, seems to be of the utmost consequence for the materialization of existence. The morals of such a society reduce the value of the individual, and women and children are those who suffer most severely.

While mothers' concern for their children is still the same, the legal and social situation has changed radically, at least in some parts of the world. The question that the short story 'The ghost children' poses to today's reader is how this change matters in a country at war. Would women and children be affected the same way today if war were to break out? What are women's options for action and resistance? These are just a few examples of how time and new contexts contribute to the complexity of fiction. Another important factor is the slowness of the medium, which is the last property to be discussed here.

\section{An extended and slow medium}

A fiction book is an extended medium, usually totalling a couple of hundred pages at least. It takes time to read a book, much longer than to read a newspaper, watch a film, or listen to a radio programme. It also takes time to write and publish it, at least compared to a newspaper or pamphlet. The long production process is connected to the permanence of the book, which, not being topical, does not need to be written in a hurry. If written discourse in comparison with spoken discourse is more elaborate or, in Chafe's words, 'overworked', then fiction is the kind of writing that ranks as the most thorough or overworked. It allows authors to write more complex stories in terms of characterization and intrigue. ${ }^{57}$ That in turn requires a slower reading, that we in a metaphorical sense carry the story with us for a long time. In this way, we become more receptive to more complex stories.

In other words, both permanence and slowness favour more complex stories. As David Herman says of the relationship between these two features, 'The increased span of time separating the production of the narrative from its interpretation and, for that matter, the longer span of time allowed for interpretation of literary narratives, facilitates complex blends of various processes with their attendant participants.58 As a result, he continues, it is sometimes difficult for readers to determine exactly how a particular phenomenon is coded or interpreted. It becomes 
apparent that the consequence (complexity) of these two properties of the medium (permanence and slowness) is also linked to the reception process (reading alone). In Herman's reading of Kafka's Metamorphosis, the ambivalence is about whether Gregor Samsa's experience as a beetle is a projection of a mental state or of actions by other characters in the narrated world. In Elgström's 'The ghost children', the narration creates uncertainty about Mrs Mayer's visions, whether the children really are sick and deformed or if it is her fear and anxiety that drives her mad.

Elgström calls her short story 'a true story'. This suggests that she wanted us to read it as if it really happened. Yes, it is in many respects a realistic story, and one which the reader has no reason to question, yet at the same time the title can be read as a deliberate attempt on Elgström's part to double encode her texts. Repeatedly, she breaks the realists' code by using decadent or expressionist imagery, whether to depict the mother's interior life or to dissolve the border between dream and reality. The language becomes an important way for her to express what to her mind is true. True, in the sense of authentic and credible, rather than documentary and real. Sometimes, a slow reading — or perhaps a rereading-is a prerequisite for this second level of interpretation to occur.

\section{Conclusion}

How then did the properties of the book as a medium affect Elgström's representation of the suffering of the First World War? She uses the medium's one and only modality, language, very efficiently. Using varied imagery she depicts the dead, wounded, and sick, her sensuous descriptions an attempt to evoke fear, abhorrence, and disgust in the reader. The descriptions' emotional intensity can also be linked to one of the genre's conventions: internal focalization. In fiction, it is possible to depict mental processes in a subjective way, and a subjective narration creates empathy and identification between character and reader. Elgström's approach, making mothers the main characters of her short stories, gives a voice to an often-forgotten dimension of the world wars: women's experiences in wartime. In her fiction, she problematized the idea of maternal pacifism that she in her journalism argues is the answer to a peaceful world. In the two short stories discussed here, 
things end badly for the women. Another genre convention-fiction itself-is open to such pessimistic endings. Elgström's anti-war prose always had more hopeful endings, a necessity for a statement of opinion intended to change the world for the better. There must be hope for the future, here and now, or how else are we supposed to believe that another, better world is possible?

A constant feature of Elgström's short stories is their ambiguity: events can be interpreted several ways and new meanings appear on rereading. Here, the slowness and permanence of the medium interact with its reception, read in solitude. The individual reader interprets the narrative based on a changing horizon of expectation which varies according to the reader and over time. New contexts give rise to new readings. In the same way, a slow reading or rereading generates new interpretations. In addition to the problematization of the ideology of maternal pacifism, this ambiguity also results in a more nuanced representation of war. Although Elgström's fiction has a clear anti-war message, the short stories are no pamphlets. They have their ambiguities and uncertainties, as for example when it comes to the question of who will be held accountable for the war. What responsibility has Mrs Mayer's husband for her situation-a man who comes home on leave and only sees healthy and happy children around the dinner table, and who does not leave until he has got her pregnant with another potential soldier for Germany's army? What role does Germany have in this? Or is it the social system, or rather its capitalism and patriarchalism, which bears ultimate responsibility? The fiction book is a medium to return to again and again, not to look for unambiguous answers, but because it bears witness to history, and at the same time speaks to the now in which it is read.

\section{Notes}

1 Susan Sontag, Regarding the pain of others (New York: Farrar, Straus \& Giroux, 2003), 114 .

2 Aristotle, Poetics, 1447a in Aristotle, Longinus, Demetrius, Poetics, longinus: On the sublime, demetrius: On style, translated by Stephen Halliwell, W. Hamilton Fyfe, Doreen C. Innes, W. Rhys Roberts, revised by Donald A. Russell, Loeb Classical Library 199 (Cambridge, MA: Harvard University Press, 1995). See Marie-Laure 
Ryan, introduction in ead. (ed.), Narrative across media: The languages of storytelling (Lincoln, Nebraska: University of Nebraska Press, 2004), 22.

3 Sofi Qvarnström, "̈̈r mediet retoriken? Medieringen av skogsfrågan under år 1894', in Marie Cronqvist et al. (eds.), Mediehistoriska vändningar (Mediehistoriskt arkiv, 25; Lund: Lunds universitet, 2014), 70-1.

4 For a discussion of various media, see, for example, Solveig Jülich et al., introduction in eid. (eds.), Mediernas kulturhistoria (Mediehistoriskt arkiv, 8; Stockholm: Statens ljud- och bildarkiv, 2008), 12-17.

5 Marie-Laure Ryan, 'Story/worlds/media: Tuning the instruments of a mediaconscious narratology', in Marie-Laure Ryan \& Jan-Noël Thon (eds.), Storyworlds across media: Toward a media-conscious narratology (Lincoln, Nebraska: University of Nebraska Press, 2014), 30.

6 Wallace Chafe, Discourse, consciousness, and time: The flow and displacement of conscious experience in speaking and writing (Chicago: University of Chicago Press, 1994), 42-3.

7 Leif Dahlberg \& Pelle Snickars, 'Inledning - mot ett transmedialt berättande', in eid. (eds.), Berättande i olika medier (Mediehistoriskt arkiv, 7; Stockholm: Statens ljud- och bildarkiv, 2008), 23.

8 Mono-modal discourse has been challenged, with the argument that the book page is visual in layout, so that there is no such thing as a mono-modal text. But I would argue that mono-modality serves a pedagogical function, underlining the fact that most fiction texts consist only of words and not images, sound, or motion.

9 Ryan 2014, 29.

10 This chapter enlarges on my work on Anna Lenah Elgström's anti-war prose in Sofi Qvarnström, Motståndets berättelser: Elin Wägner, Anna Lenah Elgström, Marika Stiernstedt och första världskriget (diss.; Möklinta: Gidlund, 2009).

11 Qvarnström 2009; for an introduction to Elgström's early work, see Catrine Brödje, Ett annat tiotal: En studie i Anna Lenah Elgströms tiotalsprosa (Stehag: Gondolin, 1998).

12 For Sweden in the First World War, see, for example, Claes Ahlund, Diktare $i$ krig: K. G. Ossiannilsson, Bertil Malmberg och Ture Nerman från debuten till 1920 (Hedemora: Gidlund, 2007); Nils-Olof Franzén, Undan stormen: Sverige under första världskriget (Stockholm: Bonnier, 1986); Lina Sturfelt, Eldens återsken: Första världskriget $i$ svensk föreställningsvärld (diss.; Lund: Sekel, 2008).

13 Claudia Lindén, Om kärlek: Litteratur, sexualitet och politik hos Ellen Key (Stockholm/Stehag: Brutus Östlings Bokförlag Symposion, 2002), 156.

14 Sharon Ouditt, Fighting forces, writing women: Identity and ideology in the First World War (London: Routledge, 1994).

15 Anna Lenah Elgström, Mödrar (Stockholm: Bonnier, 1917). All translations are my own. A special thanks to Allan Burnett for his comments on my translations.

16 Elgström 1917, 184.

17 Ryan 2004, 19.

18 The theory of fiction turns on three main definitions: ( $i$ ) a semantic definition based on fiction's relation to the real world; (ii) a syntactical definition based 
on fiction's formal traits; and (iii) a pragmatic definition based on how fiction is used; Jean-Marie Schaeffer, 'Fictional vs. factual narration', in Peter Hühn (ed.), Handbook of narratology (New York: Walter De Gruyter, 2009), 98.

19 See, for example, Den sjunde basunen (Stockholm: Tiden, 1915); En dröm (Stockholm: Svenska Andelsförlaget, 1916); 'Tvångsföreställningar' (1916), in Samtal och brev (Stockholm: Tiden, 1918); Till kvinnor (Stockholm: Svenska Freds- och skiljedomsföreningen, 1917).

20 Focalization is Gérard Genette's coinage, and builds on such concepts as point of view and omniscient narrator; Gérard Genette, 'Discours du récit', in id., Figures 3 (Paris: Seuil, 1972); id., Nouveau discours du récit (Paris: Seuil, 1983).

21 Ur 'Kaos', in Elgström 1917, 169-184.

22 Elgström 1917, 171.

23 Elgström 1917, 175.

24 Elgström 1917, 180.

25 Elgström 1917, 184.

26 Wolfgang Iser, Der Akt des Lesens: Theorie ästhetischer Wirkung (Munich: Wilhelm Fink, 1976).

27 'Spökbarnen: En sann historia', in Elgström 1917, 185-229.

28 Elgström 1917, 198.

29 Elgström 1917, 218.

30 Charles Sanders Peirce, Writings of Charles S. Peirce: A chronological edition, ii: $1867-1871$ (Peirce Edition Project; Bloomington: Indiana University Press, 1984), 56.

31 Elgström 1917, 224.

32 Elgström 1917, 227-8.

33 Elgström 1917, 229.

34 Paul Messaris, Visual 'literacy': Image, mind and reality (Boulder: Westview Press, 1994).

35 Quintilian, The orator's education, translated by Donald A. Russell, Loeb Classical Library 127 (Cambridge, MA: Harvard University Press, 2001), 9,2,40; Cicero, Rhetorica ad Herennium, translated by Harry Caplan, Loeb Classical Library 403 (Cambridge, MA: Harvard University Press, 1954), 4, 68.

36 See Brödje 1998, 210-16.

37 Kjell Espmark, Själen i bild: En huvudlinje i modern svensk poesi (Stockholm: PAN/Norstedt, 1994), 53, 56.

38 Elgström 1917, 176.

39 Brödje 1998, 63-4.

40 Anna Lenah Elgström, Innan det blir för sent (Stockholm: Bonnier, 1940), 22; see also Brödje 1998, 210-11.

41 Elgström 1917, 172.

42 Elgström 1917, 229.

43 Elgström 1917, 130.

44 Piotr Bukowski, Ordnungsschwund-Ordnungswandel: Pär Lagerkvist und der deutsche Expressionismus (Frankfurt am Main: Peter Lang, 2000), 204-208.

45 See Ahlund 2007, 390. 
46 Elgström 1917, 172.

47 Elgström 1917, 174.

48 Elgström 1917, 212-14.

49 Per Thomas Andersen, Dekadense i nordisk litteratur 1880-1900 (Oslo: Aschehoug, 1992); Claes Ahlund, Medusas huvud: Dekadensens tematik i svensk sekelskiftesprosa (Historia litterarum 18; Uppsala: Acta Universitatis Upsaliensis, 1994).

50 Ahlund 1994, 38, 42.

51 Chafe 1994, 42.

52 See, for example, Carl R. Ugglas, Svenska Dagbladet, 5 Dec. 1917; Erik Hedén, Folkets Dagblad Politiken, 6 Dec. 1917; Fredrik Vetterlund, 'Det stora medlidandets diktare', Aftonbladet, 2 Dec. 1917; 'Sign. G., Upsala Nya Tidning, 2 Jan. 1918.

53 Brödje 1998.

54 Gurli Hertzman-Ericson, 'Ur bokmarknaden', Rösträtt för kvinnor, 23 (1917); Vetterlund 1917.

55 Elgström 1917, 217.

56 Dahlberg \& Snickars 2008, 20.

57 Elgström 1917, 192.

58 David Herman, 'Toward a transmedial narratology', in Marie-Laure Ryan (ed.), Narrative across media: The languages of storytelling (Lincoln, Nebraska: University of Nebraska Press, 2004), 61.

\section{References}

Ahlund, Claes, Medusas huvud: Dekadensens tematik i svensk sekelskiftesprosa (Historia litterarum 18; Uppsala: Acta Universitatis Upsaliensis, 1994).

- Diktare i krig: K. G. Ossiannilsson, Bertil Malmberg och Ture Nerman från debuten till 1920 (Hedemora: Gidlund, 2007).

Andersen, Per Thomas, Dekadense i nordisk litteratur 1880-1900 (Oslo: Aschehoug, 1992).

Aristotle, Longinus, Demetrius, Poetics, longinus: On the sublime, demetrius: On style, translated by Stephen Halliwell, W. Hamilton Fyfe, Doreen C. Innes, W. Rhys Roberts, revised by Donald A. Russell, Loeb Classical Library 199 (Cambridge, MA: Harvard University Press, 1995).

Brödje, Catrine, Ett annat tiotal: En studie i Anna Lenah Elgströms tiotalsprosa (Stehag: Gondolin, 1998).

Chafe, Wallace, Discourse, consciousness, and time: The flow and displacement of conscious experience in speaking and writing (Chicago: University of Chicago Press, 1994).

Cicero, Rhetorica ad Herennium, translated by Harry Caplan, Loeb Classical Library 403 (Cambridge, MA: Harvard University Press, 1954).

Dahlberg, Leif \& Pelle Snickars, 'Inledning-mot ett transmedialt berättande', in Leif Dahlberg \& Pelle Snickars (eds.), Berättande i olika medier (Mediehistoriskt arkiv, 7; Stockholm: Statens ljud- och bildarkiv, 2008).

Elgström, Anna Lenah, Den sjunde basunen (Stockholm: Tiden, 1915).

-_En dröm (Stockholm: Svenska Andelsförlaget, 1916). 
-_Mödrar (Stockholm: Bonnier, 1917).

_- Till kvinnor (Stockholm: Svenska Freds- och skiljedomsföreningen, 1917).

_- 'Tvångsföreställningar' (1916), in ead., Samtal och brev (Stockholm: Tiden, 1918).

- - Innan det blir för sent (Stockholm: Bonnier, 1940).

Espmark, Kjell, Själen i bild: En huvudlinje i modern svensk poesi (Stockholm: PAN/ Norstedt, 1994).

Franzén, Nils-Olof, Undan stormen: Sverige under första världskriget (Stockholm: Bonnier, 1986).

Genette, Gérard, 'Discours du récit', in id., Figures 3 (Paris: Seuil, 1972).

- - Nouveau discours du récit (Paris: Seuil, 1983).

Herman, David, 'Toward a transmedial narratology', in Marie-Laure Ryan (ed.), Narrative across media: The languages of storytelling (Lincoln, Nebraska: University of Nebraska Press, 2004).

Iser, Wolfgang, Der Akt des Lesens: Theorie ästhetischer Wirkung (Munich: Wilhelm Fink, 1976).

Jülich, Solveig, Patrik Lundell \& Pelle Snickars, 'Introduction', in eid. (eds.), Mediernas kulturhistoria (Mediehistoriskt arkiv, 8; Stockholm: Statens ljud- och bildarkiv, 2008).

Lindén, Claudia, Om kärlek: Litteratur, sexualitet och politik hos Ellen Key (Stockholm \& Stehag: Brutus Östlings Bokförlag Symposion, 2002).

Messaris, Paul, Visual 'literacy': Image, mind and reality (Boulder: Westview, 1994).

Ouditt, Sharon, Fighting forces, writing women: Identity and ideology in the First World War (London: Routledge, 1994).

Peirce, Charles Sanders, Writings of Charles S. Peirce: A chronological edition, ii: 1867-1871 (Peirce Edition Project; Bloomington, Ind.: Indiana University Press, 1984).

Quintilian, The orator's education, translated by Donald A. Russell, Loeb Classical Library 127 (Cambridge, MA: Harvard University Press, 2001).

Qvarnström, Sofi, 'Är mediet retoriken? Medieringen av skogsfrågan under år 1894', in Marie Cronqvist, Johan Jarlbrink \& Patrik Lundell (eds.), Mediehistoriska vändningar (Mediehistoriskt arkiv, 25; Lund: Lunds universitet, 2014).

- - Motståndets berättelser: Elin Wägner, Anna Lenah Elgström, Marika Stiernstedt och första världskriget (diss.; Möklinta: Gidlund, 2009).

Ryan, Marie-Laure, 'Story/worlds/media: Tuning the instruments of a media-conscious narratology', in Marie-Laure Ryan \& Jan-Noël Thon (eds.), Storyworlds across media: Toward a media-conscious narratology (Lincoln, Nebraska: Nebraska University Press, 2014).

- - 'Introduction', in ead. (ed.), Narrative across media: The languages of storytelling (Lincoln, Nebraska: University of Nebraska Press, 2004).

Schaeffer, Jean-Marie, 'Fictional vs. factual narration', in Peter Hühn (ed.), Handbook of narratology (New York: Walter De Gruyter Berlin, 2009).

Sontag, Susan, Regarding the pain of others (New York: Farrar, Straus \& Giroux, 2003). Sturfelt, Lina, Eldens återsken: Första världskriget i svensk föreställningsvärld (diss.; Lund: Sekel, 2008). 